\title{
The role of vanillin and p-coumaric acid in the growth of Scotch pine seedlings*
}

\author{
M. MICHNIEWICZ and E. GALOCH
}

Biology Institute of Copernicus University, Laboratory of Plant Physiology, Toruń, Poland (Received: December 21, 1973.)

\begin{abstract}
It was stated that vanillin and p-coumaric acid used at concentrations $10^{-8}-10^{-5} \mathrm{M}$ stimulated the growth of pine seedlings. Most effective were these substances used at concentration $10^{-7} \mathrm{M}$. Both phenolic compounds stimulated the elongation, fresh and dry weight in very young seedlings (up to $3-4$ weeks) and increased the fresh and dry weight only in older ones (7 weeks). The stimulation of growth processes in pine seedlings treated with vanillin and p-coumaric acid coincided with the increase of auxins in roots and with the decrease of free gibberellins in these plant organs. Neither vanillin nor p-coumaric acid influenced the level of ABA-like inhibitor both in the shoots and roots of pine seedlings.
\end{abstract}

\section{INTRODUCTION}

Phenolic compounds play an essential role in the processes of growth and development of plants (Gaspar, 1965). It is very common opinion that phenolics are growth inhibitors (Hemberg, 1961, Kefeli and Kadyrov, 1971). However, there appears more and more evidences that phenolic substances may stimulate the processes of growth and development of plants (Henderson and Nitsch, 1962, Gesto et al. 1972). Some of these compounds promote the rooting process of various species (Michniewicz et al. 1974 b) and among them also the cuttings of pine (Hyun, 1969).

In preliminary experiments we have found that among several phenolic compounds tested, such as caffeic, o-coumaric, p-coumaric, p-hydroxybenzoic and ferulic acids as well as vanillin used at concentrations of $10^{-8}-10^{-4} \mathrm{M}$ only vanillin and p-coumaric acid proved to be stimulators of the elongation of very young pine seedlings. Therefore in further experiments only these phenolic substances were used.

* Research supported in part by grant from the United States Department of Agriculture, Agricultural Research Service (FG-Po-230). 
The aim of the present work was to study the influence of vanillin and p-coumaric acid on growth of pine seedlings and on the content of endogenous growth regulators in them.

\section{METHODS}

Fine seeds were germinated $24 \mathrm{hrs}$ in water at $21-23^{\circ} \mathrm{C}$ and light intensity of about 2000 lx. When the sprouts reached a length of about $1 \mathrm{~mm}$ the seeds were selected and transferred to a medium containing phenolic compounds at concentration of $10^{-4}-10^{-8} \mathrm{M}$.

Three different media for seedlings cultivation were used:

1) paper tissues (seeds were placed on diagonally situated glass plates with paper tissue), 2) sawdust (prepared from leafy trees, boiled and washed with destilled water), 3) nutrient solution according to Ingestad (1960). All seedlings were cultivated at light intensity of about $4000 \mathrm{~lx}$ and temperature of $24-27^{\circ} \mathrm{C}$.

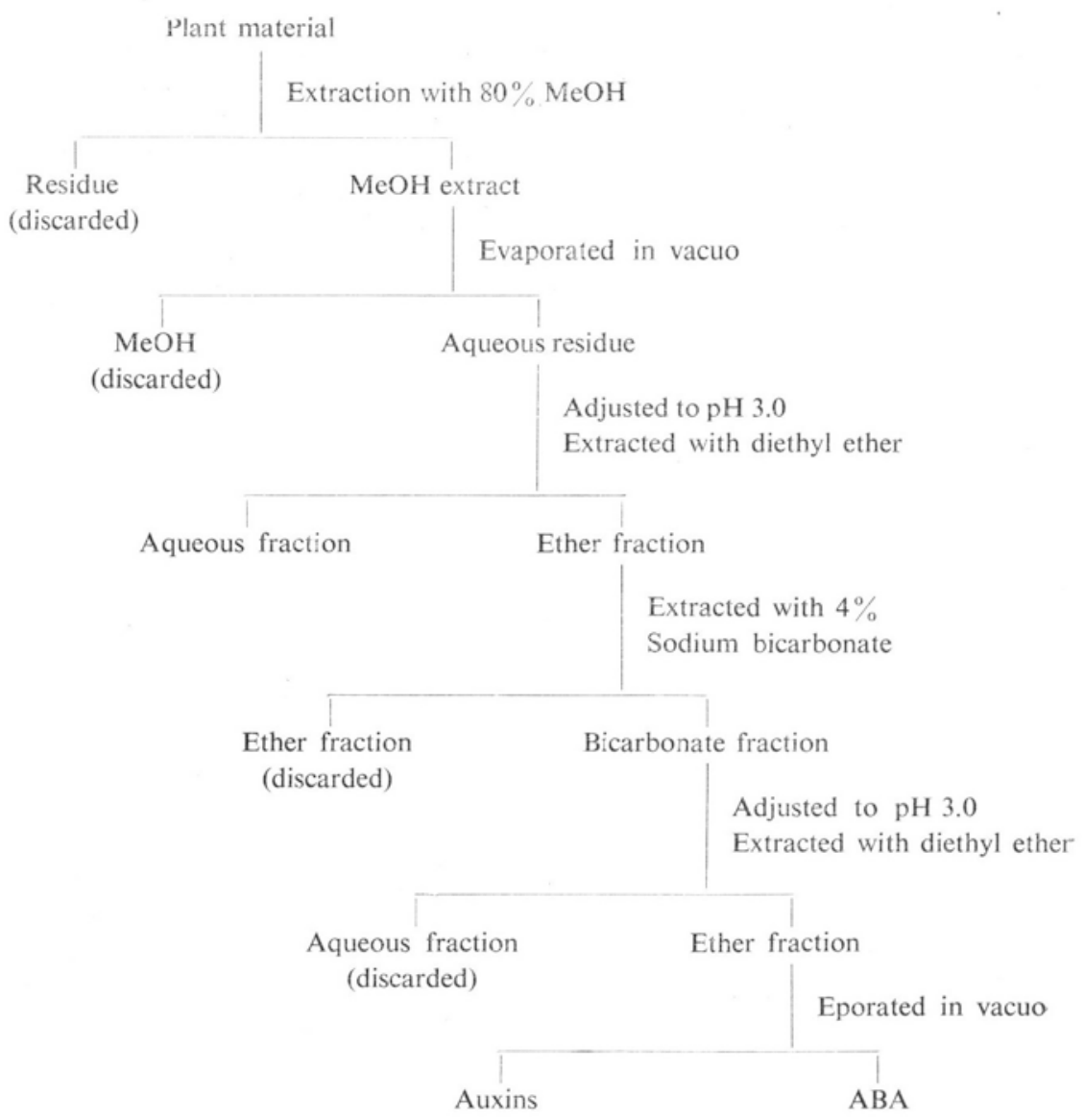

Fig. 1. Extraction and fractionation of auxins and ABA-like inhibitor 
The seedlings for chemical analyses were cultivated on the paper tissue. The seeds were germinated $96 \mathrm{hrs}$ in water or in vanillin and p-coumaric acid $\left(10^{-7} \mathrm{M}\right)$. When the sprouts reached length of about $3 \mathrm{~mm}$ they were transferred to paper tissue saturated with these compounds. Other conditions of cultivation were the same as described above.

Auxins and abscisic acid-like inhibitor were extracted from $20 \mathrm{~g}$ frozen samples with $80 \%$ metanol during $48 \mathrm{hrs}$. The method of extraction and fractionation is presented in Fig. 1.

Auxins were partitioned chromatographically on Sephadex LH-20 according to Steen and Eliasson (1969) and bioassayed by the Avena section straight growth test.

ABA-like inhibitor was partitioned by thin layer chromatography (Silica gel G, solvent system: isopropanol, butanol, ammonia, water $6: 2: 1: 2 \mathrm{v} / \mathrm{v}$ ). The active zones determined, were eluated with $1 \%$ acetic acid in methanol and rechromatographed using solvent system: benzene, acetone, acetic acid $70: 30: 1 \mathrm{v} / \mathrm{v}$. Again the active zones determined, were partitioned by paper chromatography (Whatman's No 3, descending method, solvent: redistilled water).

The activity of zones on the chromatograms was determined by estimating the UV spectrum using Universal Spectrophotometer VSU-1 and by the fiuorescence method (the fluorescence with sulphuric acid on the plates coated with Silica gel and comparison with the fluorescence of synthetic $\mathrm{ABA}$ ).

The quantity of $\mathrm{ABA}$-like inhibitor was estimated by the wheat coleoptile test (Rudnicki, 1969).

Gibberellins were extracted from $20 \mathrm{~g}$ frozen samples with $80 \%$ methanol during $48 \mathrm{hrs}$. The method of extraction and fractionation according to Rappaport et al. (1967) is presented in Fig. 2.

Gibberellins were partitioned using thin layer chromatography (solvent system: benzene - acetic acid 10:3 v/v and bioassayed using the lettuce hypocotyl test and for comparison also the test of dwarf pea).

All experiments were three times repeated. The significance of differences was established by estimating LSD at $\mathrm{P}=0.05$.

\section{RESULTS AND DISCUSSION}

Both phenolic compounds used at a concentration of $10^{-8}-10^{5} \mathrm{M}$ stimulated the growth of pine seedlings. The substances used at higher concentrations $\left(10^{-4} \mathrm{M}\right)$ inhibited the growth of seedlings. The most pronounced growth stimulation was obtained under the influence of vanillin and p-coumaric acid at concentration of $10^{-7} \mathrm{M}$.

As may be seen from the data presented in the Tables 1 and 2 more pronounced stimulative effect of phenolic compounds was stated in younger seedlings than in older ones. This is evident when comparing the influence of vanillin and p-coumaric acid on elongation of 8 days and 7 weeks old seedlings. Although the elongation of 


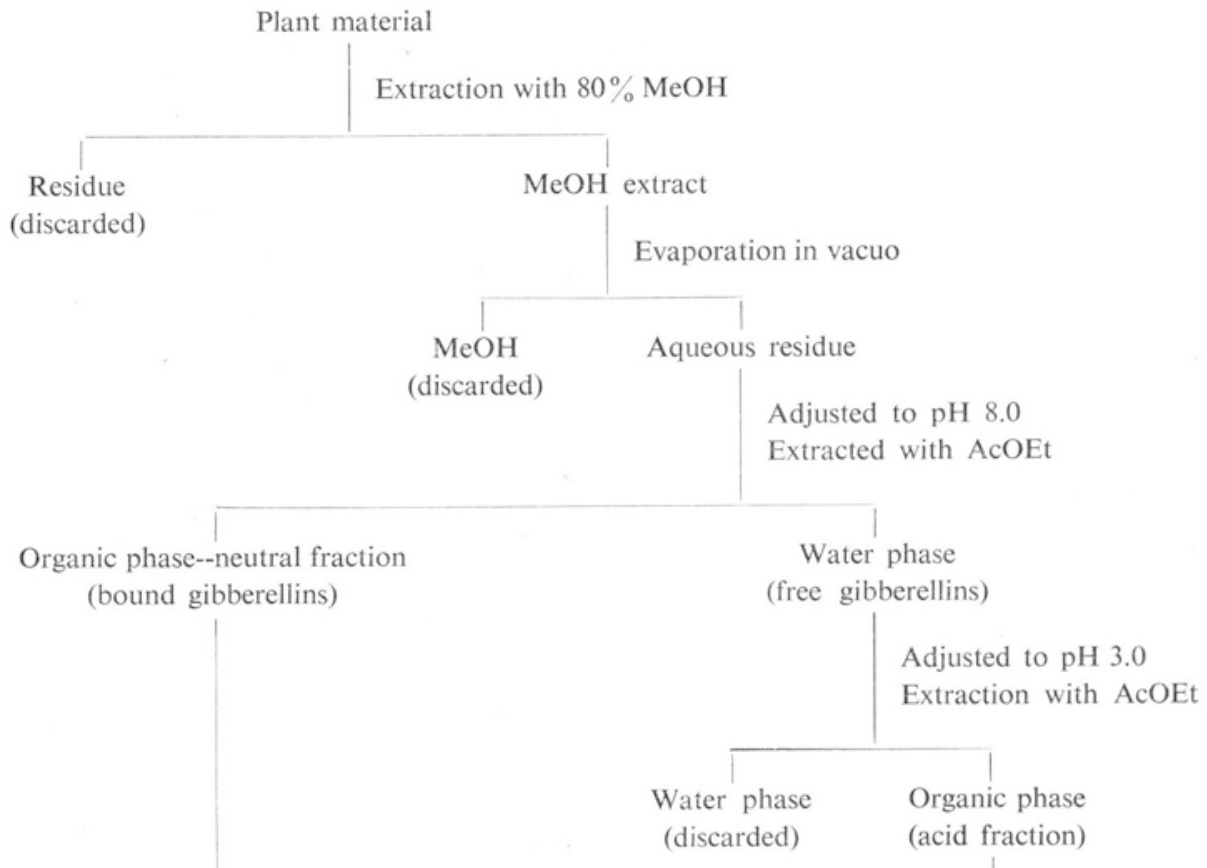

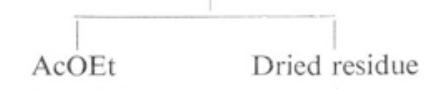

(discarded)

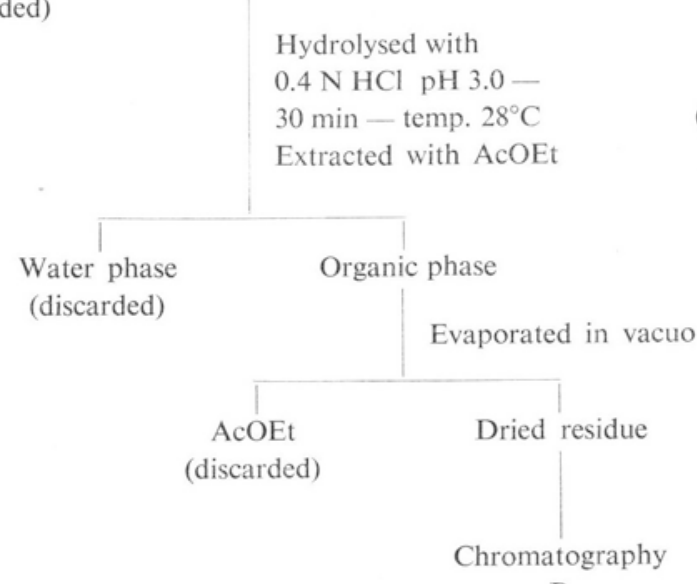

B

Fig. 2. Extraction and fractionation of free - and bound gibberellins

the oldest seedlings is inhibited by the treatment with phenolic compounds, however an increase in fresh and dry weight of shoots and roots in these plants was noted.

The endogenous growth regulators were extracted from 11 days old seedlings treated with vanillin and p-coumaric acid at a concentration of $10^{-7} \mathrm{M}$.

In such seedlings vanillin stimulated the growth of shoots in $105.4 \%$ and growth of roots in $137.3 \%$ and p-coumaric acid in 105.4 and $122.5 \%$ respectively (p.c. in relation to control $=100 \%$ ). 
Table 1

Effect of vanillin and p-coumaric acid $\left(10^{-7} \mathrm{M}\right)$ on the elongation of pine seedlings (Per cent in relation to control $=100$ p.c.)

\begin{tabular}{c|c|c|c|c|c}
\hline \multirow{2}{*}{ Kind of substance } & Plant & \multicolumn{4}{|c}{ Results after days: } \\
\cline { 5 - 7 } & organ & $8^{\mathrm{a}}$ & $14^{\mathrm{b}}$ & $28^{\mathrm{c}}$ & $49^{\mathrm{c}}$ \\
\hline \multirow{2}{*}{ vanillin } & shoots & 181.4 & 104.1 & 102.2 & 77.5 \\
& roots & 123.7 & 117.1 & 142.9 & 102.0 \\
\hline \multirow{2}{*}{ p-coumaric } & shoots & 255.5 & 123.2 & 103.3 & 90.0 \\
acid & roots & 206.6 & 129.5 & 141.0 & 88.8 \\
\hline
\end{tabular}

Cultivated: a) on paper tissue, b) in sawudst, c) in nutrient solution

Table 2

Effect of vanillin and p-coumaric acid $\left(10^{-7} \mathrm{M}\right)$ on growth of pine seedlings cultivated in nutrient solutions during 4 and 7 weeks (Per cent in relation to control $=100$ p.c.).

\begin{tabular}{|c|c|c|c|c|}
\hline \multirow{2}{*}{ Kind of substance } & \multirow{2}{*}{ Kind of measurement } & \multirow{2}{*}{$\begin{array}{l}\text { Plant } \\
\text { organ }\end{array}$} & \multicolumn{2}{|c|}{ Results after: } \\
\hline & & & 4 weeks & 7 weeks \\
\hline \multirow{6}{*}{ vanillin } & \multirow{2}{*}{ length } & shoots & 102.2 & 77.5 \\
\hline & & roots & 142.9 & 102.0 \\
\hline & \multirow{2}{*}{ fresh weight } & shoots & 106.9 & 120.4 \\
\hline & & roots & 136.5 & 132.8 \\
\hline & \multirow[b]{2}{*}{ dry weight } & shoots & 119.2 & 120.0 \\
\hline & & roots & 157.5 & 118.1 \\
\hline \multirow{6}{*}{ p-coumaric acid } & \multirow{2}{*}{ length } & shoots & 103.3 & 90.0 \\
\hline & & roots & 141.0 & 88.8 \\
\hline & \multirow{2}{*}{ fresh weight } & shoots & 108.1 & 108.9 \\
\hline & & roots & 105.1 & 159.5 \\
\hline & \multirow{2}{*}{ dry weight } & shoots & 106.5 & 120.4 \\
\hline & & roots & 127.5 & 122.4 \\
\hline
\end{tabular}

The results presented in Fig. 3 show that similarly as in experiments with willow cuttings (Michniewicz and Kriesel 1972) the roots contained a higher level of free gibberellins than the shoots. The level of bound gibberellins was however higher in shoots than in roots.

Vanillin increased the level of free GA in shoots and decreased it in roots. It had no influence on the level of bound GA. Thus, the root growth induced by vanillin was correlated with a decrease in free GA and the growth stimulation of shoots was correlated with the increase of this kind of GA.

p-coumaric acid decreased the level of free gibberellins both in the roots and in shoots. However, it increased the amount of bound gibberellins in roots and had no influence on the level of this kind of gibberellins in shoots.

So, vanillin and p-coumaric acid influenced the level of gibberellins in the roots. 


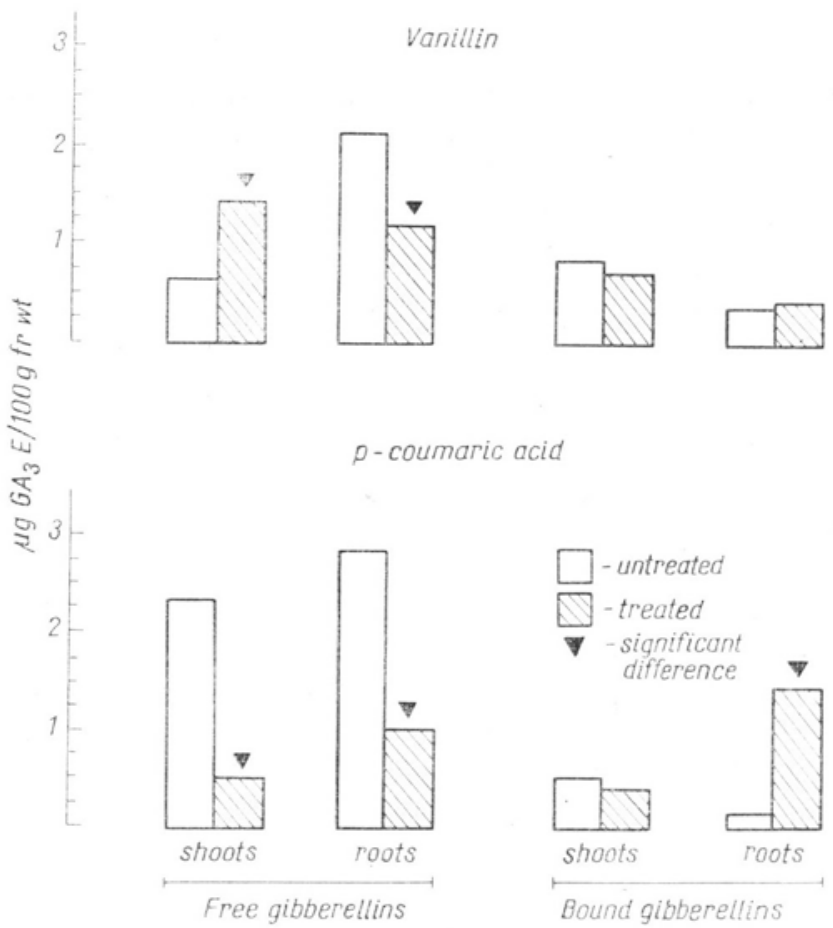

Fig. 3. Effect of vanillin and p-coumaric acid $\left(10^{-7} \mathrm{M}\right)$ on the level of gibberellins in shoots and roots of pine seedlings.

Consequently, the stimulation of growth processes in pine seedlings treated with vanillin and p-coumaric acid coincided with the decrease of free gibberellins in the roots.

As may be seen from the data presented in Fig. 4 the shoots of seedlings treated with vanillin and p-coumaric acid contained the same amount of auxins as the con-
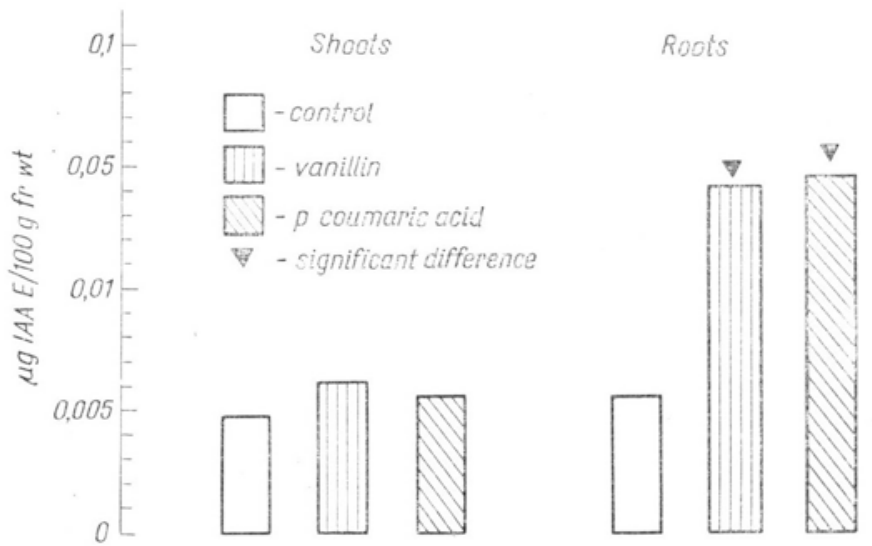

Fig. 4. Effect of vanillin and p-coumaric acid $\left(10^{-7} \mathrm{M}\right)$ on the level of auxins in shoots and roots of pine seedlings. 
trol plants. Both phenolic compounds increased however the level of auxins in roots. They had no significant infiuence on the level of ABA-like inhibitor both in the shoots and roots of pine seedlings (Tab. 3).

\section{Table 3}

Effect of vanillin and p-coumaric acid $\left(10^{-7} \mathrm{M}\right)$ on the level of ABA-like inhibitor in shoots and roots of pine seedlings (expressed as the growth inhibition of the wheat coleoptile section in p. c.)

\begin{tabular}{l|c|c}
\hline \multirow{2}{*}{ Treatment } & \multicolumn{2}{c}{ Organs } \\
\cline { 2 - 3 } & Shoots & Roots \\
\hline $\mathrm{H}_{2} \mathrm{O}$ & 30.3 & 25.0 \\
vanillin & 31.8 & 27.7 \\
p-coumaric acid & 29.8 & 25.1 \\
\hline
\end{tabular}

Differences between treatment - unsignificant

Differences between organs - significant at $\mathrm{P}=0.05$

Until now, no information concerning the influence of phenolic compounds on the level of gibberellins and abscisins are available. However, there are many data showing the effect of these substances on the level of auxins. According to the opinion of most authors phenolic substances affect auxins by influencing the IAA oxidase activity.

The results of our experiments with vanillin are in agreement with the data of Georgiev and Ivanova (1972) who found that vanillin decreased to some degree the activity of IAA oxidase in maize and pea and in this way increased the level of auxins in the experimental plants.

Data presented by different authors concerning the influence of p-coumaric acid on the activity of IAA oxidase are discording. Contrary to our results, Gortner and Kent (1958) in experiments with pineapple and Tafuri et al. (1972) in experiments with Lens culinaris found that p-coumaric acid activated IAA oxidase and in this way decreased the level of auxins. On the other hand data of Raa (1971) show that p-coumaric acid in physiological concentration do not activate IAA oxidase.

The possibility that phenolic compounds can affect the level of auxins in different ways than through influencing the IAA oxidase activity must also be considered. It was stated in our experiments that p-coumaric acid and vanillin increased the level of auxins in roots and had no influence on the amount of auxins in shoots. Thus, it is possible that the effect of these phenolic compounds reveals through the influence of auxins transport.

It appears from the data presented in Tab. 3 that there was no dependence between the growth stimulation induced by vanillin and p-coumaric acid and the influence of these compounds on the level of ABA. However these data show that similar as in Salix viminalis also in pine seedlings the level of $\mathrm{ABA}$ in roots is higher than in shoots (Michniewicz and Galoch 1972).

Taking into consideration the fact that the growth of young seedlings of Scotch pine is very slow (Michniewicz et al 1974a), the results of our experiments showing that vanillin and p-coumaric acid increase the fresh and dry weight of such seedlings 
are interesting and worth further study. If the growth stimulation induced by these compounds is indeed, significant, and has no long-term deleterious effects on the seedlings, it could conceivably be used in seedling production on a large scale. This could easily be achieved with vanillin, which can be produced cheaply from waste lignin derived from paper making.

\section{CONCLUSIONS}

Vanillin and p-coumaric acid stimulated the growth of pine seedlings. Most effective were the substances used at the concentration of $10^{-7} \mathrm{M}$.

More stimulative effect of these phenolic compounds was stated in younger seedlings. Both substances stimulated the elongation, fresh and dry weight in very young seedlings and increased the fresh and dry weight only in older ones.

The stimulation of growth processes coincided with the increase of auxins in roots and with the decrease of free gibberellins in these plant organs.

\section{REFERENCES}

Gaspar T., 1966. Action de quelques composés phénoliques sur l'activité auxines-oxydasique, la teneur en auxines et la croissance. Les congrés et colloques de l'Universite de Liège 38: 41-53.

Georgiev G. H., Ivanova Y. A., 1972. Influence of certain chemical compounds of the group of natural inhibitors on growth and auxin-inhibitory balance in plants, C.R. Bulg. Acad. Sci. 25: $819-822$.

Gesto M. D. V., Vázquez A., Méndez J., Vieitez E., Seoane E., 1967. Growth substances isolated from woody cuttings of Quercus robur L. and Juglans regia L., Phytochemistry 6: 1687-1693.

Gortner W. A., Kent M. J., 1958. The coenzyme requirement and enzyme inhibitors of pine apple indoleacetic acid oxidase. J. Biol. Chem. 233:731-735.

Hemberg T. 1961. Biogenous inhibitors, Encyclop. Plant Physiol. 14: 1162-1184.

Henderson J. H. M., Nitsch J. P., 1962. Effect of certain phenolic acids on the elongation of Avena first internode in the presence of auxins and tryptophan, Nature 195: 780 - 782.

Hy un S. K., 1969. Studies on endogenous growth substances controlling root initiation of cuttings in Pinus rigida Mill and Populus alba L., XI International Bot. Congress, Seattle, Abstracts: 98.

Ingestad T., 1960. Studies on the nutrition of forest tree seedlings. III Mineral nutrition of pine, Physiol. Plant. 13: 513-533.

Kefeli V. I., Kadyrov Ch. Sh., 1971. Natural growth inhibitors, their chemical and physiological properties, Ann. Rev. Plant Physiol. 22: 185-196.

Michniewicz M., Galoch E., 1972. Dynamics of endogenous inhibitor of abscisic acid properties in the development of buds, newly formed shoots and adventitious roots of willow cuttings (Salix viminalis L.), Bull. Acad. Polon. Sci. Ser. Biol. 20: 333-337.

Michniewicz M., Galoch E., Rożej B., 1974a. Dynamics of endogenous plant growth regulators in the early stages of growth and development of Scotch pine seedlings. Bull. Acad. Polon. Sci. Ser. Biol. (in press).

Michniewicz M., Kriesel K., 1972. Dynamics of gibberellin-like substances in the development of buds, newly formed shoots and adventitious roots of willow cuttings (Salix viminalis L.), Acta Soc. Bot. Pol. 41: 301-310. 
Michniewicz M., Lamparska K., Galoch E., 1974b. The influence of ferulic acid on the process of rooting. Bull. Acad. Polon. Sci. Ser. Biol. (in press).

R a a J., 1971, Degradation of indol-3yl-acetic acid in homogenates and segments of cabbage roots, Physiol. Plant. 24: 498-505.

Rappaport L., Hsu A., Thompson R., Yang S. F., 1967. Fate of ${ }^{14}$ C-gibberellin $A_{3}$ in plant tissues. Ann. New York Acad. Sci. 144: 2111-218.

Rudnicki R., 1969. Studies on abscisic acid in apple seeds. Planta (Berl.) 86: 63-68.

Steen J., Eliasson L., 1969. Separation of growth regulators from Picea abies Karst. on Sephadex LH-20, J. Chromatog. 43: 558-560.

Tafuri F., Businelli M., Scarponi L., 1972. Effect of caffeic and p-coumaric acids on indole-3-acetic acid catabolism. J. Sci. Fd Agric. 23: 1417-1423.

\author{
Authors' address \\ Prof. dr Marian Michniewicz \\ Mgr Elizbieta Galoch \\ Institute of Biology, N. Copernicus University, \\ ul. Gagarina 9, 87-100 Toruń, Poland
}

Rola waniliny $i$ kwasu p-kumarowego we wzroście pędów $i$ korzeni siewek sosny zwyczajnej

\title{
Streszczenie
}

Skiełkowane w wodzie nasiona sosny przenoszono do środowiska (bibuła, trociny lub płynna pożywka) zawierającego wanilinę i kwas p-kumarowy w różnych stężeniach i hodowano je na świetle. Wyrosłe w tych warunkach siewki mierzono określając długość, świeżą i suchą masę części nadziemnej i korzeni oraz oznaczano w nich poziom auksyn, giberelin i inhibitora o właściwościach kwasu abscysynowego.

Stwierdzono, że oba związki fenolowe stosowane w stężeniach $10^{-8}-10^{-5} \mathrm{M}$ stymulowały elongację oraz świeżą i suchą masę części nadziemnej i korzeni u bardzo młodych siewek (do 3-4 tygodni) a u siewek starszych (7 tygodni) zwiększały tylko świeżą i suchą masę. Największą aktywnością odznaczały się związki stosowane w stężeniu $10^{-7} \mathrm{M}$.

Analizie chemicznej poddano siewki 11-to dniowe potraktowane związkami fenolowymi w stężeniu $10^{-7}$ M. Stwierdzono, że stymulacja wzrostu wywołana działaniem waniliny i kwasu p-kumarowego była skorelowana $\mathrm{z}$ jednoczesnym zwiększeniem poziomu auksyn w korzeniach oraz z obniżeniem wolnych giberelin w tych organach. Oba stosowane związki nie miały wplywu na poziom inhibitora o właściwościach ABA. 